\title{
Risk factors for surgical site infections after caesarean section at Yaounde, Cameroon
}

\author{
Pierre M. Tebeu ${ }^{1}$, Aurelien Kamdem², Jean P. Ngou-Mve-Ngou ${ }^{3}$, Esther Meka ${ }^{4}$, \\ Jesse S. S. Antaon ${ }^{1 *}$, Meukem Tegue Loic ${ }^{2}$, Jeanne Fouedjio
}

\author{
${ }^{1}$ Inter-State Center for Higher Education in Public Health of Central Africa (CIESPAC), Brazzaville, Congo \\ ${ }^{1}$ Faculty of Medicine and Biomedical Sciences, University of Yaounde, Yaoundé, Cameroon \\ ${ }^{3}$ Department of Obstetrics and Gynecology, University Hospitals, Librevillle, Gabon \\ ${ }^{4}$ Department of Obstetrics and Gynecology, Yaounde Gyneco-Obstetrics and Pediatric Hospital, Yaoundé, Cameroon
}

Received: 17 September 2021

Accepted: 08 October 2021

\author{
*Correspondence: \\ Jesse S. S. Antaon, \\ E-mail: antaonjesesaintsaba@gmail.com
}

Copyright: (C) the author(s), publisher and licensee Medip Academy. This is an open-access article distributed under the terms of the Creative Commons Attribution Non-Commercial License, which permits unrestricted non-commercial use, distribution, and reproduction in any medium, provided the original work is properly cited.

\section{ABSTRACT}

Background: Surgical site infection is the invasion by microorganisms of the tissue layers affected by the surgical procedure. Maternal morbidity from infections has been shown to be higher after caesarean section compared to the vaginal delivery. Objective of the research was to analyze the risk factors associated with surgical site infections after caesarean section.

Methods: This was a cross sectional (affected/non affected) study approved by the institutional committee for ethics and research of the faculty of medicine and biomedical sciences. A total of 310 medical files were assessed, 62 files from patients with surgical site infections and 248 files from patients without any complications. The data was collected using a pretested questionnaire and analyzed using the statistical package for the social sciences (SPSS) software version 22.0. The Chi squared and the Fisher exact tests were used to assess homogeneity between the 2 groups. Odd ratio $95 \%$ confidence interval was used to assess the association between the variables.

Results: The proportion of surgical site infections during the study was $1.81 \%$. Factors associated with surgical site infections were premature rupture of membranes (OR: 2.065; 95\% CI 1.051-4.05; $\mathrm{p}=0.035$ ); the vertical midline incision $(\mathrm{OR}=5.26 ; 95 \% \mathrm{CI} ; 1.41-19.57 ; \mathrm{p}=0.013)$ and a operation by a resident physician doctor $(\mathrm{OR}=1.98 ; 95 \% \mathrm{CI}$ $1.09-3.59 ; \mathrm{p}=0.02)$.

Conclusions: A factors associated with surgical site infections after caesarean section are a premature rupture of membranes, vertical midline incision and the qualification of the practitioner.

Keywords: Risk factors, Frequency, Infection, Cesarean section

\section{INTRODUCTION}

Caesarean section is a surgical procedure that allows delivery by incision through the abdomen and the uterus when conditions of mother or child are not favorable for natural childbirth. ${ }^{1}$ Initially used to bypass an insurmountable mechanical obstacle, it has become a means to limit fetal trauma and fetal suffering in many pathological situations surgery. ${ }^{2}$ Its indications are very broad and concern mother, fetus or both.
It is worth noting that, there has been a change in frequency worldwide. The caesarean section rate has been increasing rapidly for several years. In France, the caesarean section rate had increased to $20.8 \%$ in 2010 as compared to $15.5 \%$ in 1995 , in the United States from $21 \%$ in 1998 to $32 \%$ in 2007 and in Cameroon, between 2004 and 2011 the percentage of births per caesarean section increase from $2 \%$ to $3.8 \%$ before dropping to $2.4 \%$ in 2014. . $^{-5}$ Infectious complications being a common morbidity after caesarean section. Infection is one of the 
leading causes of maternal mortality. ${ }^{6}$ Studies in developing countries revealed that $15 \%$ of maternal death were attributed to infections. ${ }^{6}$

\section{Objectives}

Objectives of the study were to identify the factors associated with surgical site infections occurrence after cesarean section at Yaounde Central Hospital (CHY), Gyneco-Obstetrics and Pediatric Hospital of Yaounde (GOPHY) and Yaounde University Hospital Center (CHUY).

\section{METHODS}

\section{Type-place-periode}

We conducted a 5 months retrospective cross sectional (affected/non affected) study from 20 December 2017 to 20 April 2018 at the HGOPY, YUHC and the YUCH.

\section{Sampling}

Our sampling was consecutive and exhaustive. The study population consisted of all women admitted to the HGOPY, CHUY, and HCY who were treated for surgical site infection after caesarean section and patients who delivered via cesarean without any post-partum infection. All women who did not consent to the study were excluded.

\section{Variables}

Data was collected using a pre-tested questionnaire. Variables of interest were: age, educational level, profession, parity, gravity, premature rupture of membranes, $3^{\text {rd }}$ trimester genital tract infection, urinary tract infection in pregnancy, history of cesarean section, type of incision, type of caesarean section, type of anaesthesia, surgeon's qualification, and antibiotic prophylaxis.

\section{Statistical analysis}

All statistical analyzes were performed using Epi-Info version 7.2.2.6. The comparison of variables was carried out using the student $t$ test and Chi square test. To identify risk factors for surgical site infections after cesarean section, we used an unconditional logistic regression. Multivariate analysis was used in order to determine the model that was more predicting. Confounding variables used in the multivariate model were selected based on the heterogeneity observed at bivariate analysis or with $\mathrm{p}<0.24$. The level of significance was set up at $\mathrm{p}<0.05$.

\section{RESULTS}

A total of 310 medical files were assessed, 62 files from patients with surgical site infection and 248 files from patients who had no infectious complications. The age of the study populations varied from 14 to 46 years. The mean age of infected patients was $26.82 \pm 5.63$ years and that of uninfected patients was $27.83 \pm 5.95$ years.

The proportion of surgical site infections during our study was $1.81 \%$. Factors associated with surgical site infections occurrence were premature rupture of membranes (OR: 2.06; 95\% CI 1.05-4.05; $\mathrm{p}=0.035)$; the vertical midline an incision $(\mathrm{OR}=5.267 ; 95 \% \mathrm{CI}$; 1.41-19.57; $\mathrm{p}=0.013)$ and an operation by a resident doctor $(\mathrm{OR}=1.98 ; 95 \%$ CI 1.09 3.59; $\mathrm{p}=0.024)$ (Table 1).

Table 1: Multi-varied regression of factors associated with surgical site infections.

\begin{tabular}{|c|c|c|c|c|c|c|c|c|c|}
\hline \multirow{4}{*}{ Characteristics } & \multicolumn{9}{|c|}{ Post-caesarean section infection } \\
\hline & \multirow{3}{*}{$\begin{array}{l}\text { Total } \\
\mathbf{N}=\mathbf{3 1 0} \\
\text { n }\end{array}$} & \multirow{2}{*}{\multicolumn{2}{|c|}{$\begin{array}{l}\text { Yes } \\
\mathrm{N}=62\end{array}$}} & \multirow{2}{*}{\multicolumn{2}{|c|}{$\begin{array}{l}\text { No } \\
N=248\end{array}$}} & \multirow{3}{*}{ 'OR (CI 95\%) } & \multirow{3}{*}{$\begin{array}{l}P \\
\text { value }\end{array}$} & \multirow{3}{*}{ a'OR (CI 95\%) } & \multirow{3}{*}{$\begin{array}{l}P \\
\text { value }\end{array}$} \\
\hline & & & & & & & & & \\
\hline & & $\mathbf{n}$ & $\%$ & $\mathbf{n}$ & $\%$ & & & & \\
\hline \multicolumn{10}{|l|}{ PRM $^{\text {b }}$} \\
\hline No & 251 & 42 & 16.7 & 209 & 83.3 & $1^{r}$ & & $1^{r}$ & \\
\hline Yes & 59 & 20 & 33.9 & 39 & 66.1 & $2.17(1.02-4.63)$ & 0.043 & $2.06(1.05-4.05)$ & 0.035 \\
\hline \multicolumn{10}{|l|}{ Type of incision } \\
\hline Pfannenstiel & 281 & 52 & 18.5 & 229 & 81.5 & $1^{\mathrm{r}}$ & & $1^{\mathrm{r}}$ & \\
\hline Median & 11 & 6 & 54.5 & 5 & 45.5 & $4.24(1.01-17.75)$ & 0.047 & $5.26(1.41-19.575)$ & 0.013 \\
\hline Joël-Cohen & 13 & 4 & 30.8 & 9 & 69.2 & $1.12(0.25-5.02)$ & 0.877 & $1.63(0.45-5.90)$ & 0.455 \\
\hline Others & 5 & 0 & 0 & 5 & 100 & & & - & - \\
\hline \multicolumn{10}{|c|}{ Type of caesarean section } \\
\hline Elective & 44 & 5 & 11.4 & 39 & 88.6 & $1^{\mathrm{r}}$ & & $1^{r}$ & \\
\hline Emergency & 266 & 57 & 21.4 & 209 & 78.6 & $2.127(0.80-5.64)$ & 0.130 & $1.60(0.54-4.75)$ & 0.394 \\
\hline \multicolumn{10}{|l|}{ Surgeon $^{a}$} \\
\hline Gynecologist & 184 & 28 & 15.2 & 156 & 84.8 & $1^{\mathrm{r}}$ & & $1^{\mathrm{r}}$ & \\
\hline Resident & 126 & 34 & 27 & 92 & 73 & $2.73(1.42-5.27)$ & 0.003 & $1.98(1.09-3.59)$ & 0.024 \\
\hline \multicolumn{10}{|c|}{ Type of anaesthesia } \\
\hline Rachidian & 200 & 33 & 16.5 & 167 & 83.5 & $1^{\mathrm{r}}$ & & $1^{\mathrm{r}}$ & \\
\hline
\end{tabular}




\begin{tabular}{|c|c|c|c|c|c|c|c|c|c|}
\hline \multirow{4}{*}{ Characteristics } & \multicolumn{9}{|c|}{ Post-caesarean section infection } \\
\hline & \multirow{3}{*}{$\begin{array}{l}\text { Total } \\
\mathbf{N}=\mathbf{3 1 0} \\
\mathrm{n}\end{array}$} & \multirow{2}{*}{\multicolumn{2}{|c|}{$\begin{array}{l}\text { Yes } \\
\mathrm{N}=62\end{array}$}} & \multirow{2}{*}{\multicolumn{2}{|c|}{$\begin{array}{l}\text { No } \\
\mathrm{N}=\mathbf{2 4 8}\end{array}$}} & \multirow{3}{*}{ 'OR (CI 95\%) } & \multirow{3}{*}{$\begin{array}{l}P \\
\text { value }\end{array}$} & \multirow{3}{*}{ aOR (CI 95\%) } & \multirow{3}{*}{$\begin{array}{l}P \\
\text { value }\end{array}$} \\
\hline & & & & & & & & & \\
\hline & & n & $\%$ & n & $\%$ & & & & \\
\hline General & 110 & 29 & 26.4 & 81 & 73.6 & $1.81(1.03-3.19)$ & 0.039 & $1.61(0.87-2.96)$ & 0.125 \\
\hline \multicolumn{10}{|c|}{ Antibioprophylaxis $^{\mathrm{d}}$} \\
\hline No & 300 & 57 & 19 & 243 & 81 & $1^{\mathrm{r}}$ & & $1^{\mathrm{r}}$ & \\
\hline Yes & 10 & 5 & 50 & 5 & 50 & $4.26(1.19-15.22)$ & 0.026 & $2.28(0.56-9.25)$ & 0.245 \\
\hline
\end{tabular}

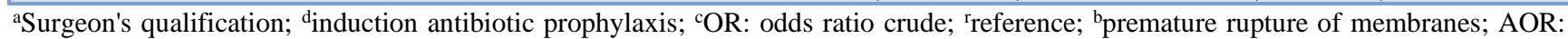
adjusted odds ratio

\section{DISCUSSION}

We found the prevalence of surgical site infection of $1.81 \%$. Our result is similar to that from Norway who had a prevalence of $1.2 \% .^{7}$ A lower prevalence than our was reported in China in 2012 had a prevalence of $0.7 \% .^{8}$ Other authors have shown higher prevalence than our ranging from $2.6 \%$ to $9.1 \% .^{9-14}$ The mild prevalence ranging from $2.6 \%$ to $4.1 \%$ where reported in the United States, in Paris and India. ${ }^{12,13,15}$ The highest prevalence ranging, from 5\% to $9.04 \%$ were reported in United States, Estonia, Cameroon, Nigeria. ${ }^{9-11,14}$ The lower prevalence of surgical infection observed in this study could be the result of the quality of care in the three study setting that are university teaching hospitals. More over our study took place in central level hospitals of the health pyramid with better post-operative follow-up.

The mean age of our study population was $27.63 \pm 5.89$ years, ranging from 14 to 46 years almost similar in both groups. This result is similar to the one found in Tanzania where the participants' age varied from 14 to 44 years, with the mean of $26.8 \pm 5.8$ years. A study in France found an average age of $31 \pm 6$ years with extremes of 19 and 45 years. ${ }^{13}$ The mean age higher than ours is in light with the early initiation of pregnancies and deliveries in our environment.

We found that patients with premature rupture of membranes had a double risk of developing surgical site infection. This result is similar from China, which showed a triple risk of developing surgical site infection after premature rupture of membrane. ${ }^{8}$ This result could be explained by the fact that the PROM itself is already an infectious risk and the infection could spread contiguously during the Caesarean section, thus reaffirms the importance of proper management of premature rupture of membranes.

The risk of developing surgical site infection after caesarean section was associated with the practitioner's qualification. Caesarean sections performed by residents had a double risk of infectious complications. This result is similar to that from Ethiopia where a triple risk for infection was reported when caesarean section was performed by a resident physician. ${ }^{16}$ Similar report with double risk was found in the United Kingdom. ${ }^{17}$ In Tanzania a fourfold risk of infection was reported while comparing resident doctor to the gynecologists. ${ }^{18}$ In India a five-fold risk was reported. ${ }^{12}$ This could be explained by the fact that residents are the ones available along even during the night and therefore perform more emergency caesarean sections than consultant gynecologists. Additionally, this result could be due to the fact that gynecologists have more skills than residents in preventing and supervising the prevention of infection during caesarean section. These observations underscore the necessity, the competence of resident doctors on the measures for preventing infections.

The median incision was found as associated with the risk of surgical site infections. This result is similar to the one found by Thornburg et al in the United States in 2012 (vertical $45.7 \%$ versus $11.6 \%$ transverse; $\mathrm{p}<0.01$ ). ${ }^{19}$ This could be explained by the fact that this incisions, is mainly used during emergency caesarean section, condition that could be associated with less infection prevention measure due to the stressful condition. We can justify this by the fact that this type of incision is most often used in cases of maternal obesity, which is usually associated with comorbidities such as diabetes. ${ }^{19}$ Similarly, this type of incision is most often used by inexperienced personnel.

\section{Limitations}

The data collection being retrospective, we could have recall bias.

\section{CONCLUSION}

Factors associated with surgical site infections after caesarean section are premature rupture of membranes, vertical midline incision and the qualification of the practitioner. Our findings highlight the need of discouraging the midline incision for caesarean section, proper management premature rupture of membranes, to reinforce the competency of resident doctors on infection prevention measures.

\section{ACKNOWLEDGMENTS}

Authors would like to thank all the staff of the obstetrical gynaecology services of the different hospitals for their efforts in facilitating this study. 
Funding: No funding sources

Conflict of interest: None declared

Ethical approval: The study was approved by the Institutional Ethics Committee

\section{REFERENCES}

1. U.S. National librery of medicine. Cesarean Section A Brief History: Part 1. Available at: https://www.nlm.nih.gov/exhibition/cesarean/part1.h tml. Accessed on 10 November 2017.

2. Lurie S, Glezerman M. The history of cesarean technique. Am J Obstet Gynecol. 2003;189(6):18036.

3. Deneux-Tharaux C. Utérus cicatriciel: aspects épidémiologiques. J Gynécologie Obs Biol la Reprod. 2012;41(8):697-707.

4. Nkwabong E, Kouam L. Indication des cesariennes a la maternite du CHU de Yaounde de 2000 A 2004. Clin Mother Child Heal. 2006;3(1):453-5.

5. Monitoring report of 100 key health indicators in Cameroon in 2017. 2018. Available at: $\mathrm{http} / / / \mathrm{cdnss} . \mathrm{minsante} . \mathrm{cm} / \mathrm{qq}=\mathrm{fr} /$ content/rapport-desuivi-des-100-indicateurs-cles-de-sante-aucameroun-en-2017. Accessed on 10 November 2017.

6. Leke R. Mortalite Maternelle. Postgrad Res Train Reprod Heal. 2004. Available from: https://www.gfmer.ch/Medical_education_En/Camer oon/Pdf/Mortalite_maternelle_Leke.pdf. Accessed on 20 November 2017.

7. Vitenskap M. Infections after caesarean sections. J Nor Med Assoc. 2009;(1):2-6.

8. Gong S, Guo H, Zhou H, Chen L, Yu Y. Morbidity and risk factors for surgical site infection following cesarean section in Guangdong Province, China. J Obstet Gynaecol Res. 2012;38(3):509-15.

9. Mitt P, Lang K, Peri A, Maimets M, National P. Surgical -site infections following cesarean section in an estonian $\mathrm{u}$ niversity hospital: postdischarge surveillance. Infect Control Hosp Epidemiol. 2005;26(5):449-54.

10. Jido T, Garba I. Surgical-site infection following cesarean section in Kano, Nigeria. Ann Med Health Sci Res. 2012;2(1):33-6.

11. Ngowa JDK, Ngassam A, Fouogue JT, Metogo J, Medou A, Kasia JM. Complications maternelles précoces de la césarienne: A propos de 460 cas dans deux hopitaux universitaires de Yaoundé, Cameroun. Pan Afr Med J. 2015;21:265.

12. Vijayan CP, Mohandas S, Nath AG. Surgical Site Infection Following Cesarean Section in a Teaching Hospital. Intern Journ Sci Study. 2016;3(12):97-101.

13. Goderel I, Lejeune V, Milliez J. Travail original Infections de site opératoire chez les patientes. J Gynecol Obs Biol Reprod. 2011;33:487-96.

14. Olsen MA, Butler AM, Willers DM, Devkota P, Gross GA, Fraser VJ. Risk Factors for Surgical Site Infection After Low Transverse Cesarean Section. Infect Control Hosp Epidemiol. 2008;29(06):477-84.

15. Killian CA, Graffunder EM, Vinciguerra TJ, Venezia RA. risk factors for surgical-site infections. Infect Control Hosp Epidemiol. 2014;22(10):613-7.

16. Wodajo S, Mehretu Belayneh SG. Magnitude and Factors Associated With Post-Cesarean Surgical Site Infection at Hawassa University Teaching and Referral Hospital, Southern Ethiopia: A Crosssectional Study. Ethopian J Heal Sci. 2017;27(3):28390.

17. Wloch $\mathrm{C}$, Wilson J, Lamagni $\mathrm{T}$, Harrington $\mathrm{P}$, Charlett A, Sheridan E. Risk factors for surgical site infection following caesarean section in England: Results from a multicentre cohort study. BJOG An Int J Obstet Gynaecol. 2012;119(11):1324-33.

18. Mpogoro FJ, Mshana SE, Mirambo MM, Kidenya BR, Gumodoka B, Imirzalioglu C. Incidence and predictors of surgical site infections following caesarean sections at Bugando Medical Centre, Mwanza, Tanzania. Antimicrob Resist Infect Control. 2014;3(25):1-10.

19. Thornburg LL, Linder MA, Durie DE, Walker B, Pressman EK, Glantz JC. Risk factors for wound complications in morbidly obese women undergoing primary cesarean delivery. J Matern Neonatal Med. 2012;25:1544-8.

Cite this article as: Tebeu PM, Kamdem A, NgouMve-Ngou JP, Meka E, Antaon JSS, Loic MT, et al. Risk factors for surgical site infections after caesarean section at Yaounde, Cameroon. Int $\mathbf{J}$ Reprod Contracept Obstet Gynecol 2021;10:4048-51. 